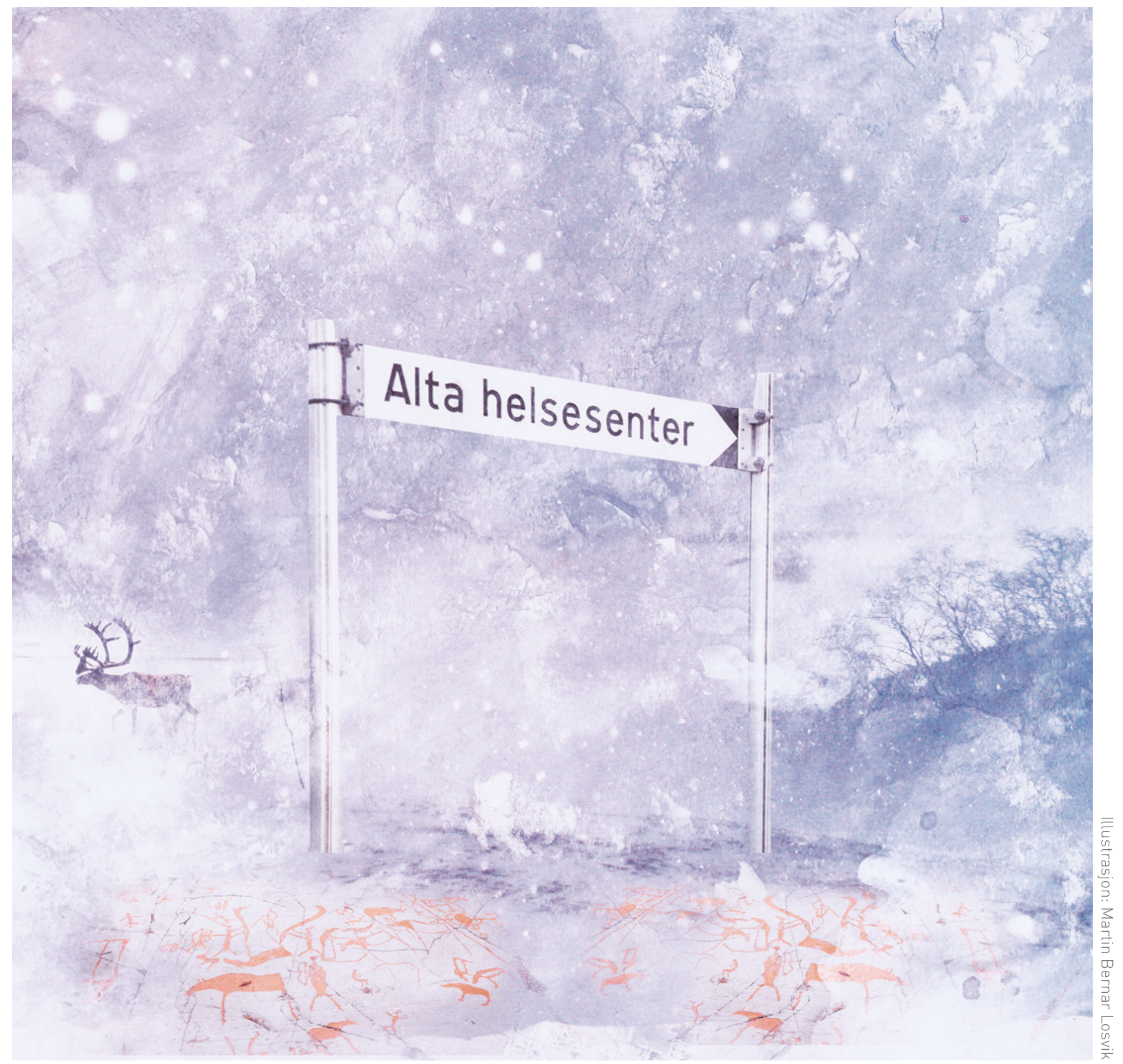

\title{
Alta helsesenter
}

(

Systemet i kommunen er kjent som «Altamodellen». Alta har 20000 innbyggere, og nærmeste sykehus er 140 kilometer unna (i Hammerfest). Alta helsesenter er på størrelse med et sykehus, uten å være det. Det drives kommunalt, statlig og privat, med 400 ansatte, og inneholder legesenter, legevakt, ambulansetjeneste, fødestue, sykestue, DPS, spesialistpoliklinikk og mye, mye mer. 